\title{
Review
}

\section{Rickettsia africae: identifying gaps in the current knowledge on vector- pathogen-host interactions}

\author{
Estere Mazhetese ${ }^{1}$, Vlademiro Magaia², Elisa Taviani' ${ }^{2,3}$, Luis Neves ${ }^{1,2}$, Darshana Morar-Leather ${ }^{1}$ \\ ${ }^{1}$ Department of Veterinary Tropical Diseases, University of Pretoria, Onderstepoort, Gauteng, South Africa \\ ${ }^{2}$ Eduardo Mondlane University, Maputo, Mozambique \\ ${ }^{3}$ University of Sassari, Sassari, Italy
}

\begin{abstract}
Rickettsia africae is a bacterium of zoonotic importance, which causes African tick bite fever (ATBF) in humans. This pathogen is transmitted by ticks of the genus Amblyomma, with Amblyomma hebraeum and Amblyomma variegatum being the major vectors. Tick species other than the above-mentioned have also been reported to carry $R$. africae DNA. There is scarcity of information on the epidemiology of this pathogen, yet several cases have been recorded in foreign travellers who visited endemic areas, especially southern Africa. The disease has rarely been described in people from endemic regions. The aim of this study was to discuss the information that is currently available on the epidemiology of $R$. africae, highlighting the gaps in this field. Furthermore, ATBF cases, clinical signs and the locations where the cases occurred are also listed in this review.
\end{abstract}

Key words: Rickettsia africae; African tick bite fever; Amblyomma hebraeum.

J Infect Dev Ctries Ctries 2021; 15(8):1039-1047. doi:10.3855/jidc.13291

(Received 17 June 2020 - Accepted 29 January 2021)

Copyright $(C 2021$ Mazhetese et al. This is an open-access article distributed under the Creative Commons Attribution License, which permits unrestricted use, distribution, and reproduction in any medium, provided the original work is properly cited.

\section{Introduction}

Rickettsia africae is a bacterium that was first reported as a species 24 years ago [1]. It is mainly transmitted by African Amblyomma tick species, causing African tick bite fever (ATBF) in humans; mostly in tourists visiting southern Africa [2].

This paper reviews $R$. africae from the epidemiological perspective, looking at the occurrence of ATBF among individuals from presumed naïve populations never exposed to African Amblyomma bites, and those from endemic regions, where the populations are commonly exposed to $R$. africae challenge, the potential vectors of this disease in Africa and other continents, and the possible role of mammalian hosts as reservoirs.

\section{Methodology}

Review design

Articles with information related to ATBF, $R$. africae, tick bite fever, South African tick bite fever, and data on the seroprevalence of ATBF were gathered. Articles written in any language other than English were not included, except for those of historical importance. Searches had no restriction on the research period. Data on ATBF cases reported worldwide were also gathered and ATBF cases included in this study (Table 1) were only those reported from 2004 onwards. This review does not include six ATBF reports which were published from 1996 to 2003, however, two references supporting the cases reported during this time interval were included in this paper. The cases reported in this paper are sufficient in terms of geographic representation and individuals involved and period of cases.

\section{Materials}

The databases Medline, Science Direct, PubMed, Google scholar and Google.com were used to perform the searches for publications on the topic. Some articles were retrieved from citations and reference lists in papers on the related topic. The first search date was the $10^{\text {th }}$ of June 2018 and the last search on google.com was conducted on the $6^{\text {th }}$ of June 2019; the last search date for other databases was the $14^{\text {th }}$ of June 2019.

\section{Study selection}

Duplicates were removed and articles were selected if their titles and abstracts were related to ATBF, $R$. africae, tick bite fever, South African tick bite fever or ATBF seroprevalence. 


\section{Data collection}

Articles reporting ATBF cases were included in this review, irrespective of geographical region. In addition, papers focussing on the diagnosis of ATBF and detection of $R$. africae were also included. Among the articles reporting ATBF cases, only those published from 2004 onwards were considered. Unusual clinical signs of ATBF in humans, which are symptoms not usually reported to be associated with ATBF, and the detection of $R$. africae in tick species other than Amblyomma were also noted. Additionally, Amblyomma tick hosts are discussed since they are likely to play a major role in the epidemiology of $R$. africae.

\section{Results}

Data on cases of ATBF in presumed naïve populations and those from endemic regions were collected. For all articles reporting case studies, the following data were tabulated: the year of publication, age of affected persons, gender, nationality, country visited (if any), purpose of the visit to the area where the infection was acquired, the clinical signs presented in each case and the diagnostic method used (Table 1). Unusual clinical signs of ATBF in humans and the detection of $R$. africae in tick species other than Amblyomma were also included (Table 2).
From 36 ATBF reports, 57 recorded ATBF patients were included in this study. This disease was also found to occur as clustered cases since more than one person would be affected. This review includes seven reports of clustered ATBF cases. Out of the 57 patients included in this study, 40 had information on sex and age. Between the age zero to 29 years there were two females and six males, between 30-60 years, there were 11 females and 13 males, between 61 and 90 years, three were females and five were males. Out of the 57 cases mentioned, only three were reported from the endemic areas, two from South Africa and one from Zimbabwe and the rest were from international travellers who had visited African countries for various activities as indicated on Table 1.

The most common ATBF clinical signs were headache, fever, eschars, rash, lymphadenopathy, myalgia, chills, malaise and arthralgia. Some unusual clinical signs were also reported in some patients and these were; myocarditis, pericarditis, conjunctivitis, decreased vision, floaters, panuveitis, and neurological signs such as feacal incontinence, urinary retention, hyperesthesia, depressed and significant irritability. ATBF was also found to have neurological complications in elderly patients.

Table 1. Some of the African tick bite fever cases that have been published worldwide from 2004 to June 2019 (See methodology for selection criteria).

\begin{tabular}{|c|c|c|c|c|c|c|c|c|}
\hline Year & $\begin{array}{c}\text { Country of } \\
\text { origin }\end{array}$ & $\begin{array}{l}\text { No. of } \\
\text { people }\end{array}$ & $\begin{array}{l}\text { Sex and age } \\
\text { (years) }\end{array}$ & Country of travel & Purpose of travel & Clinical presentation & Diagnostic techniques & References \\
\hline 1992 & Zimbabwe & 1 & $F(36)$ & $\begin{array}{l}\text { None, Indigenous } \\
\text { person }\end{array}$ & No history of travel & $\begin{array}{l}\text { Eschar, fever, severe headache } \\
\text { lymphadenopathy, }\end{array}$ & $\begin{array}{l}\text { PCR and restriction endonuclease } \\
\text { fragment length polymorphism with } \\
\text { oligonucleotide primer pairs for } \\
\text { 190kDA, 120kDA. Restriction } \\
\text { endonucleases Rsa1, Pst1 }\end{array}$ & Kelly et al. [11] \\
\hline 2004 & $\begin{array}{l}\text { United } \\
\text { States }\end{array}$ & 1 & $\mathrm{M}(62)$ & Zambia and Malawi & Safari and sight seeing & $\begin{array}{l}\text { Eschar, lymphangitis, fever, regional } \\
\text { lymphadenopathy }\end{array}$ & Serology & Uslan [39] \\
\hline \multirow{3}{*}{2004} & \multirow{3}{*}{ Switzerland } & \multirow{3}{*}{4} & $\mathrm{M}(55)$ & \multirow{3}{*}{ South Africa } & \multirow{3}{*}{ Safari } & Myalgia, headache, neck pain, nausea & \multirow{3}{*}{ Serology } & \multirow{3}{*}{$\begin{array}{l}\text { Jackson et al. } \\
\quad[40]\end{array}$} \\
\hline & & & $\mathrm{M}(11)$ & & & $\begin{array}{l}\text { Headache, asthenia, eschar, lymphadenitis, } \\
\text { rash } \\
\text { Myalgia, neck muscle pain, fever, rash, } \\
\text { asthenia, } \$ \text { hyperesthesia of both arms, } \\
\text { \$significant irritability, } \neq \text { depressed mood }\end{array}$ & & \\
\hline & & & $\mathrm{F}(46)$ & & & Fever, arthro-myalgia, rash, headache & & \\
\hline 2004 & Switzerland & 5 & $\dagger$ & South Africa & Safari & $\begin{array}{c}\text { Eschars, fever } 1 \text {, Headache } 4 \text {, myalgia } 2, \\
\text { shivering } 1, \text { lymphadenopathy } 2\end{array}$ & Serology & Althaus [31] \\
\hline 2005 & Switzerland & 2 & $\begin{array}{l}\text { M (35) } \\
\mathrm{F}(35)\end{array}$ & $\begin{array}{l}\text { South Africa and } \\
\text { Swaziland }\end{array}$ & Campaign & 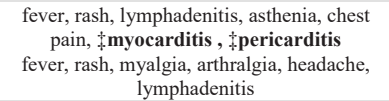 & Serology & Bellini et al. [41] \\
\hline 2006 & $\begin{array}{l}\text { United } \\
\text { States }\end{array}$ & 1 & $\mathrm{M}(13)$ & Zimbabwe & Safari & $\begin{array}{l}\text { Fever, malaise, myalgia, headache, eschars, } \\
\text { lymphadenopathy }\end{array}$ & $\begin{array}{l}\text { Blood culture and blood smears } \\
\text { negative, diagnosis based on symptoms }\end{array}$ & $\begin{array}{l}\text { Snape and } \\
\text { Pollard [42] }\end{array}$ \\
\hline 2006 & $\begin{array}{l}\text { United } \\
\text { States }\end{array}$ & 1 & $\mathrm{~F}(48)$ & Zimbabwe & $\begin{array}{l}\text { Mission trip, History of } \\
\text { visiting game farm }\end{array}$ & $\begin{array}{l}\text { Fever, malaise, eschars, lymphadenopathy, } \\
\text { anorexia, dizziness }\end{array}$ & $\begin{array}{l}\text { Immunohistochemistry of eschar tissue } \\
\text { was positive for SFG rickettsia, } \\
\text { Serologic PCR negative }\end{array}$ & Owen et al. [43] \\
\hline 2008 & France & 8 & $\mathrm{M}$ and $\mathrm{F}$ & South Africa & Safari & $\begin{array}{l}\text { Fever (6 cases), chills ( } 7 \text { ), headaches (5), } \\
\text { myalgias, asthenia, anorexia, weight loss, } \\
\text { eschars (5), rash (7), +conjunctivitis (4), } \\
\text { lymphadenitis ( } 2)\end{array}$ & $\begin{array}{c}\text { Culture on eschars followed by PCR, } \\
\text { Serology }\end{array}$ & Roch et al. [44] \\
\hline 2008 & $\begin{array}{l}\text { South } \\
\text { Africa }\end{array}$ & 1 & F (3) & None, Indigenous & General visit & $\begin{array}{c}\text { Fever, headache, regional } \\
\text { lymphadenopathy, eschar on scalp, } \\
\text { maculopapular rash }\end{array}$ & $\dagger$ & Frean et al. [9] \\
\hline 2008 & Germany & 1 & $\mathrm{~F}(60)$ & South Africa & $\dagger$ & Fever, chills, vesicular exanthema & Serology & $\begin{array}{c}\text { Schuster et al. } \\
\text { [45] }\end{array}$ \\
\hline 2009 & France & 1 & $\mathrm{~F}(43)$ & South Africa & Safari & Fever, fatigue, headache, muscle pain, & Serology, Western blotting & $\begin{array}{c}\text { Consigny et al. } \\
{[46]}\end{array}$ \\
\hline
\end{tabular}


Table 1 (continued). Some of the African tick bite fever cases that have been published worldwide from 2004 to June 2019 (See methodology for selection criteria).

\begin{tabular}{|c|c|c|c|c|c|c|c|c|}
\hline Year & $\begin{array}{c}\text { Country of } \\
\text { origin }\end{array}$ & $\begin{array}{l}\text { No. of } \\
\text { people }\end{array}$ & $\begin{array}{l}\text { Sex and age } \\
\text { (years) }\end{array}$ & Country of travel & Purpose of travel & Clinical presentation & Diagnostic techniques & References \\
\hline 2009 & Taiwan & 1 & $F(62)$ & South Africa & Safari and leisure & $\begin{array}{l}\text { Mild fever, eschars, skin nodules, } \\
\text { erythematous papules }\end{array}$ & $\begin{array}{c}\text { Serology, Nested PCR (Suicide PCR } \\
\text { using primers; AF3F, AF3R, AF4F, } \\
\text { AF4R followed by AF5F, AF5R, } \\
\text { AF6F, AF6R) }\end{array}$ & Tsai et al. [47] \\
\hline 2009 & Germany & 1 & $\mathrm{~F} \uparrow$ & South Africa & Safari & Fever, headache, malaise & $\begin{array}{l}\text { Serology, Pan-Rickettsia real time PCR } \\
\text { and sequencing of gltA }\end{array}$ & Tappe et al. [48] \\
\hline 2010 & Poland & 1 & $\mathrm{M}(51)$ & South Africa & Safari & $\begin{array}{c}\text { Fever, chills, eschar, generalised cutaneous } \\
\text { rash }\end{array}$ & PCR & $\begin{array}{c}\text { Tomasiewicz et } \\
\text { al. [49] }\end{array}$ \\
\hline 2012 & $\begin{array}{l}\text { United } \\
\text { States }\end{array}$ & 1 & $\mathrm{~F}(52)$ & $\begin{array}{c}\text { Zambia and } \\
\text { Botswana }\end{array}$ & Work and safari & $\begin{array}{l}\text { Fever, eschar, mild headache, non- } \\
\text { productive cough, chills, sweating }\end{array}$ & Clinical signs & $\begin{array}{c}\text { Schwartz et al. } \\
{[50]}\end{array}$ \\
\hline 2013 & Poland & 1 & M (45) & South Africa & Safari & $\begin{array}{l}\text { Fever, generalised muscle pain and } \\
\text { weakness, eschars, maculopapular rash on } \\
\text { trunk and arms, lymphadenopathy }\end{array}$ & $\begin{array}{c}\text { Serology, Rickettsia-specific PCR - } \\
\text { gltA, omp } A, 17-\mathrm{kDA} \text { genes, } \\
\text { Sequencing of glt } A \text { and } 17-\mathrm{kDA} \text { genes }\end{array}$ & $\begin{array}{c}\text { Chmielewski et } \\
\text { al. [51] }\end{array}$ \\
\hline 2013 & Germany & 1 & M (47) & South Africa & Vacation & $\begin{array}{l}\text { Fever, eschar, regional lymphadenopathy, } \\
\text { headache, malaise }\end{array}$ & $\begin{array}{l}\text { IFA, PCR, laboratory tests - elevated } \\
\text { C-reactive protein }\end{array}$ & Antal et al. [52] \\
\hline 2014 & $\begin{array}{l}\text { United } \\
\text { States }\end{array}$ & 1 & $\mathrm{M}(76)$ & South Africa & Hunting & $\begin{array}{l}\text { Headache, muscle weakness, fever, eschars } \\
\text { on leg, regional lymphadenopathy }\end{array}$ & $\begin{array}{l}\text { Routine histology and culture done on } \\
\text { FNA of affected LN }\end{array}$ & $\begin{array}{l}\text { Yankura and } \\
\text { Ioffreda [53] }\end{array}$ \\
\hline 2014 & Italy & 1 & $\mathrm{~F}(40)$ & Zimbabwe & $\begin{array}{l}\text { Work (mission hospital- } \\
\text { medical doctor) }\end{array}$ & $\begin{array}{l}\text { Fever, eschar on L leg, fatigue, neurological } \\
\text { syndrome with severe pain of left leg, } \\
\text { urinary retention, faecal incontinence } \\
\$ \text { Neurological symptoms }\end{array}$ & 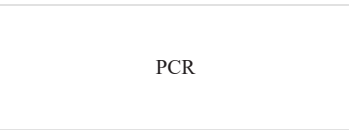 & $\begin{array}{l}\text { Zammarchi } \text { et al. } \\
{[36]}\end{array}$ \\
\hline 2015 & Netherlands & 2 & $\begin{array}{l}M(53) \\
F(51)\end{array}$ & South Africa & Safari & $\begin{array}{l}\text { Fever, eschar, regional lymphadenopathy, } \\
\text { maculopapular rash on extremities, shoulder } \\
\text { pains radiating to neck (myalgias) } \\
\text { Headache, eschar, maculopapular rash of } \\
\text { extremities, fever }\end{array}$ & History and clinical signs & $\begin{array}{c}\text { Cox and Visser } \\
{[54]}\end{array}$ \\
\hline 2015 & $\begin{array}{l}\text { United } \\
\text { States }\end{array}$ & 1 & $\mathrm{~F}(15)$ & South Africa & $\begin{array}{l}\text { History of handling a tick } \\
\text { infested antelope } \\
\text { carcass and hiking in bushy } \\
\text { areas }\end{array}$ & $\begin{array}{l}\text { Fever, headache, eschar, regional } \\
\text { lymphadenopathy }\end{array}$ & PCR & $\begin{array}{l}\text { Hohaty and } \\
\text { Hebert [55] }\end{array}$ \\
\hline 2015 & France & 1 & $\mathrm{M}(66)$ & South Africa & 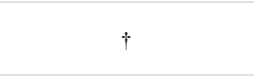 & $\begin{array}{l}\text { Headache, myalgia, odynophagia, fever, } \\
\text { eschars }\end{array}$ & PCR & $\begin{array}{c}\text { Franon and } \\
\text { Manckoundia } \\
{[56]}\end{array}$ \\
\hline 2015 & $\begin{array}{l}\text { United } \\
\text { States }\end{array}$ & 1 & $\mathrm{M}(63)$ & $\begin{array}{l}\text { India and South } \\
\text { Africa }\end{array}$ & Safari and general visit & $\begin{array}{l}\text { Fever, night sweats, myalgia, arthralgias, } \\
\text { generalised stiffness, eschar on lateral hip, } \\
\text { ulcers on neck }\end{array}$ & Serology & $\begin{array}{l}\text { Binder and } \\
\text { Gupta [57] }\end{array}$ \\
\hline \multirow{2}{*}{2015} & \multirow{2}{*}{ Sweden } & 1 & M (56) & South Africa & Safari & Fever, eschar on thorax & \multirow{2}{*}{$\begin{array}{l}\text { Serology, Western blotting, PCR and } \\
\text { sequencing - gltA, 17-kDA, ompB, }\end{array}$} & \multirow{2}{*}{$\begin{array}{l}\text { Nilsson et al. } \\
\quad[35]\end{array}$} \\
\hline & & 1 & $\mathrm{M}(41)$ & Zimbabwe & Visit rural and urban & $\begin{array}{l}\text { Fever, malaise, painful swelling in the groin } \\
\text { region, regional lymphadenopathy }\end{array}$ & & \\
\hline 2016 & $\begin{array}{l}\text { United } \\
\text { States }\end{array}$ & 1 & $\mathrm{M}(30)$ & Kenya & Safari & $\begin{array}{l}\text { Fever, chills, sweats, fatigue, eschar, } \\
\text { lymphadenopathy }\end{array}$ & Serology, PCR & Hauser et al. \\
\hline 2016 & Canada & 1 & $\mathrm{~F}(67)$ & Africa & Safari & $\begin{array}{c}\text { Fever, malaise, eschar on elbow, rash, } \\
\$ \text { decreased vision, floaters, pan-uveitis } \\
\text { and retinitis } \\
\$ \text { Retinitis }\end{array}$ & Serology & $\begin{array}{l}\text { Duval and } \\
\text { Merrill [37] }\end{array}$ \\
\hline 2016 & Austria & 1 & $\mathrm{~F}(30)$ & Tanzania & Work & $\begin{array}{l}\text { Fever, chills, headache, general malaise, } \\
\text { eschar myalgia, lymphadenopathy }\end{array}$ & $\begin{array}{l}\text { PCR and sequencing - glt } A, \text { omp } B, \\
16 \mathrm{~S} \text { rRNA, 23S-5S intergenic spacer }\end{array}$ & $\begin{array}{c}\text { Harrison et al. } \\
{[59]}\end{array}$ \\
\hline 2016 & Slovenia & 1 & M (29) & Uganda & $\dagger$ & Eschar, regional lymphadenopathy, fever & $\begin{array}{c}\text { Serology, PCR and sequencing }- \text { glt } A \\
\text { gene }\end{array}$ & $\begin{array}{l}\text { Bogovic et al. } \\
{[60]}\end{array}$ \\
\hline \multirow{2}{*}{2017} & \multirow{2}{*}{ Spain } & \multirow{2}{*}{3} & M (7) & \multirow{2}{*}{ South Africa } & \multirow{2}{*}{ Safari } & $\begin{array}{l}\text { Fever, headache, myalgia, generalised } \\
\text { erythematous papules, lymphadenopathy }\end{array}$ & R. africae PCR on blood sample & \multirow{2}{*}{$\begin{array}{c}\text { Albizuri et al. } \\
\quad[61]\end{array}$} \\
\hline & & & $\begin{array}{l}\mathrm{M}(8) \\
\mathrm{M}(16)\end{array}$ & & & $\begin{array}{l}\text { Fever, headache, myalgia, multiple eschar, } \\
\text { regional lymphadenopathy }\end{array}$ & Serology & \\
\hline 2017 & Argentina & 3 & $\mathrm{M} \dot{+}$ & South Africa & Game hunting & $\begin{array}{l}\text { All three of them presented with arthralgias, } \\
\text { regional lymphadenitis, fever, chills, eschars }\end{array}$ & $\begin{array}{l}\text { Serology, PCR - gltA, ompA, the } \\
\text { specific Spotted Fever Group gene D, } \\
\text { Sequencing omp } A \text { gene }\end{array}$ & $\begin{array}{l}\text { Armitano et al. } \\
{[62]}\end{array}$ \\
\hline 2017 & Canada & 1 & $\mathrm{M}(51)$ & South Africa & Safari & $\begin{array}{l}\text { Headache, diffuse myalgia and arthralgias, } \\
\text { chills, fever, fatigue, reduced appetite, eschar }\end{array}$ & History and clinical signs & $\begin{array}{c}\text { Liao and Carr } \\
{[63]}\end{array}$ \\
\hline 2017 & Germany & 1 & M (73) & South Africa & Safari & $\begin{array}{l}\text { General malaise, fever, regional } \\
\text { lymphadenopathy, eschars on legs, arms and } \\
\text { trunk }\end{array}$ & Serology & $\begin{array}{l}\text { Menzer et al. } \\
{[64]}\end{array}$ \\
\hline 2017 & $\begin{array}{l}\text { United } \\
\text { States }\end{array}$ & 1 & $\mathrm{M}(53)$ & South Africa & Safari & $\begin{array}{c}\text { Eschar, general malaise, myalgia, regional } \\
\text { lymphadenopathy }\end{array}$ & PCR and sequencing - ompA & Strand et al. [65] \\
\hline 2018 & Netherlands & 1 & $\mathrm{~F}(61)$ & South Africa & Safari & $\begin{array}{l}\text { Headache, myalgia in lower back, fever, } \\
\text { multiple skin lesions, maculopapular rash on } \\
\text { both legs, eschars }\end{array}$ & History and clinical signs & Geffen et al. [66] \\
\hline 2018 & Brazil & 1 & $\mathrm{M}(32)$ & South Africa & Safari & $\begin{array}{c}\text { Fever, headache, eschar, diarrhoea, regional } \\
\text { lymphadenopathy }\end{array}$ & $\begin{array}{l}\text { Eschar cultured, PCR and sequencing - } \\
\text { gltA, ompA, ompB, 17kDA }\end{array}$ & $\begin{array}{c}\text { Angerami et al. } \\
\text { [67] }\end{array}$ \\
\hline 2019 & $\begin{array}{l}\text { South } \\
\text { Africa }\end{array}$ & 1 & M (31) & United States & Farm worker & Headache, myalgia, fever, chills, & $\begin{array}{l}\text { History, Clinical signs and response } \\
\text { to Doxycycline }\end{array}$ & $\begin{array}{c}\text { Johnson et al. } \\
{[68]}\end{array}$ \\
\hline
\end{tabular}

$\dagger$ : Unknown data; $\bar{\uparrow}$ New African Tick Bite Fever feature and they are in bold; M: Male; F: Female; The cases which are in bold report ATBF in patients from ATBF endemic areas. 


\section{Discussion}

Historical background

Fever associated to tick bites was first reported in southern Africa in 1911 by Nuttall, who named it "tick bite fever" (TBF) $[3,4]$. The disease was also termed Boutonneuse fever by Conor and Bruch after its first discovery in Tunisia in 1910 [5].

In the 1930s, Pijper noted differences between the clinical signs of the disease that was termed 'TBF', identified in southern Africa in 1911, and those of Boutonneuse fever, discovered in North Africa in 1910 [6-8]. In addition, he noted differences both in the epidemiology and clinical severity of the two diseases. Boutonneuse fever had more severe clinical signs as compared to TBF. Pjiper's peers refuted his findings and attributed the differences in the severity of the two diseases to the age differences between the people who were affected [1,9]. However, Pjiper's observations are currently accepted [10]. In fact Pjiper possibly isolated the causative agent of ATBF in the 1930's and demonstrated that it was different from $R$. conorii by cross-protection assays (Pjiper 1936, Arch.Inst. Pasteur Tunis 25, 388-401 as cited by Fournier et al. (1998) [8].

The discovery of $R$. africae

Amblyomma hebraeum tick bites were found to be associated with TBF in Africa in the 1990s, and many cases were reported in southern Zimbabwe [1]. This was consistent with Pijper's report, in which he indicated that $A$. hebraeum ticks were predominant in southern Rhodesia (now Zimbabwe) [7].

In 1992, a 36-year-old Zimbabwean woman presented at a hospital in Chiredzi, a small town in south-east Zimbabwe, with fever, headache, regional lymphadenopathy and inoculation eschar, but no cutaneous rash. A blood sample was collected from the patient on the fifth day after presentation. DNA was extracted and restriction fragment length polymorphism (RFLP) were performed [11]. The isolate was found to be the same as those collected from $A$. hebraeum from several regions in Zimbabwe [1], as well as a spotted fever group (SFG) rickettsiae isolate from Ethiopia [12]. This new isolate was named Rickettsia africae in

Table 2. Tick species, other than Amblyomma, in Africa in which $R$. africae DNA was found.

\begin{tabular}{|c|c|c|c|c|}
\hline Tick & Host & Country & Method & Reference \\
\hline Haemaphysalis elliptica & Dogs & South Africa & PCR and Sequencing & Kolo et al. [69] \\
\hline $\begin{array}{l}\text { Haemaphysalis } \\
\text { paraleachi }\end{array}$ & Dogs and goats & Guinea & PCR and sequencing & Mediannikov et al. [70] \\
\hline Hyalomma dromedarii & Camels & Algeria & PCR and Sequencing & Kernif et al. [71] \\
\hline Hyalomma dromedarii & Camels and cattle & Egypt & PCR and sequencing & Abdel-shafy et al. [72] \\
\hline Hyalomma impeltatum & Camels and cattle & Egypt & PCR and sequencing & Abdel-shafy et al. [72] \\
\hline Hyalomma marginatum & Camels and cattle & Egypt & PCR and sequencing & Abdel-shafy et al. [72] \\
\hline & Cattle & Guinea & PCR and sequencing & Mediannikov et al. [70] \\
\hline Hyalomma rufıpes & Cattle & Senegal & PCR and sequencing & Sambou et al. [73] \\
\hline Hyalomma truncatum & Cattle, sheep, goats & Kenya & PCR and sequencing & Mutai et al. [74] \\
\hline $\begin{array}{l}\text { Rhipicephalus } \\
\text { (Boophilus) annulatus }\end{array}$ & Cattle, sheep, goats & Guinea & PCR and sequencing & Mediannikov et al. [70] \\
\hline & Cattle & Ethiopia & PCR and sequencing & Hornok et al. [75] \\
\hline Rhipicephalus & Cattle, sheep, dogs, cats & Ethiopia & PCR and sequencing & Kumsa et al. [76] \\
\hline (Boophilus) decoloratus & Cattle & Guinea & PCR and sequencing & Mediannikov et al. [70] \\
\hline & Cattle & Nigeria & PCR and sequencing & Ogo et al. $[77]$ \\
\hline $\begin{array}{l}\text { Rhipicephalus } \\
\text { (Boophilus) geigyi }\end{array}$ & Cattle & Liberia & PCR and sequencing & Mediannikov et al. [70] \\
\hline $\begin{array}{l}\text { Rhipicephalus } \\
\text { (Boophilus) microplus }\end{array}$ & Cattle and goats & Union of the Comoros & PCR and sequencing & Yssouf et al. [78] \\
\hline & Cattle & Kenya & PCR and sequencing & Mutai et al. [74] \\
\hline $\begin{array}{l}\text { Rhipicephalus } \\
\text { appendiculatus }\end{array}$ & Cattle and goats & Union of the Comoros & $\begin{array}{l}\text { Rickettsia africae- } \\
\text { specific qPCR reaction } \\
\text { and sequencing }\end{array}$ & Yssouf et al. [78] \\
\hline Rhipicephalus evertsi & $\begin{array}{l}\text { Cattle, sheep, goats, } \\
\text { donkeys, horses }\end{array}$ & Senegal & PCR and sequencing & Mediannikov et al. [79] \\
\hline Rhipicephalus pulchellus & Cattle, sheep, goats & Kenya & PCR and sequencing & Mutai et al. [74] \\
\hline $\begin{array}{l}\text { Rhipicephalus } \\
\text { sanguineus sensu lato }\end{array}$ & Dogs & Nigeria & PCR and sequencing & Ogo et al. [77] \\
\hline $\begin{array}{l}\text { Rhipicephalus } \\
\text { compositus }\end{array}$ & Cattle & Kenya & PCR and sequencing & Macaluso et al. [80] \\
\hline
\end{tabular}


1996, after it was proved that two different Rickettsiae species were causing two different rickettsial diseases in southern Africa [1]. Tick bite fever, caused by $R$. africae, was found to be associated with a history of travel to grasslands and game parks, whereas, Boutonneuse fever, caused by $R$. conorii, was associated with a history of contact with the dog ticks, Rhipicephalus sanguineus, Rhipicephalus simus, and Haemaphysalis leachi [11] in peri-urban or peridomestic settings. Humans infected with this pathogen showed severe clinical signs, which were associated with high mortality rates [1].

\section{Biology and characteristics of $R$. africae}

Rickettsia africae is an obligate intracellular, Gramnegative coccobacillus [13]. It was proved by electron microscopy that this bacterium can be found within the cytoplasm of host cells and has an outer slime layer as well as a tri-laminar cell wall. The cell wall of $R$. africae contains lipopolysaccharide antigens. These are highly immunogenic and responsible for extensive crossreactivity with other species of SFG rickettsiae [13]. Species-specific protein antigens are found in the highmolecular-weight rickettsial outer membrane protein $\mathrm{A}$ (rOmpA) and B (rOmpB). The rOmpA protein seems to be specific to SFG rickettsiae [14]. Most species of the SFG rickettsiae have been characterized by SDSpolyacrylamide gel electrophoresis (PAGE), Western blot and PCR-RFLP analysis [14]. The bacterium cannot be cultured in cell-free media. However, it can grow in the yolk sacs of developing chicken embryos, and in cell cultures [1].

\section{Detection of R. africae}

The methods commonly used to detect and confirm the presence of $R$. africae in tissue are PCR and sequencing respectively. A quantitative PCR (qPCR) targeting the citrate synthase gene ( gltA) is the most frequently used Rickettsiae genus-screening assay [15]. After screening, glt $A$ positive samples are usually tested in a conventional PCR (cPCR) targeting the omp $A$ gene of SFG rickettsiae [15] and more recently, a qPCR targeting the ITS gene was developed for the same purpose [16]. Sequencing is the only method currently available to identify SFG rickettsiae at species level.

\section{Amblyomma vectors of $R$. africae}

It is generally accepted that the ticks that transmit $R$. africae in Africa belong to the genus Amblyomma of the family Ixodidae (hard ticks), with $A$. variegatum and A. hebraeum being the main vectors [13]. A. hebraeum is mainly distributed in southern Africa and $A$. variegatum in West, Central and eastern Africa, as well as in the eastern Caribbean [17]. A. variegatum is also present in some parts of southern Africa where it extends into Zambia, north eastern Botswana, the Caprivi Strip of Namibia, Angola, north western Zimbabwe and central and northern Mozambique. It also occurs in Madagascar and several Indian Ocean islands [17].

Amblyomma hebraeum tick species are considered to be the main vector of $R$. africae in South Africa [13]. The infestation of humans by this species and infection with $R$. africae is relatively common due to the wide distribution of the tick vector in rural areas of the country. Rickettsia africae infection rates of up to $100 \%$ have been detected by PCR and sequencing in Amblyomma ticks from endemic areas $[18,19]$. The $A$ hebraeum and $A$. variegatum tick species are three-host ticks and all active developmental stages (larvae, nymphs and adults) have been proved to be potential vectors of Rickettsiae [20,21]. Studies performed by Kelly (1991) and Mason and Socolovschi et al. (2009), reported that these tick vectors can maintain $R$. africae through transovarial and trans-stadial transmission through two generations [22,23].

Rickettsia africae DNA was also detected in Amblyomma lepidum, Amblyomma gemma, Amblyomma cohaerens, and Amblyomma compressum in Sudan, Djibouti [23], and in the Somali region of Ethiopia $[16,19]$. Furthermore, $R$. africae was also detected in Amblyomma loculosum, a tick species that is usually known for infesting marine birds in tropical islands $[24,25]$. $R$. africae DNA was found in Amblyomma ovale ticks collected from dogs in Nicaragua, Central America, in 2013. This was the first report on $R$. africae in the American continent [26]. Given the documented distribution of $R$. africae among African Amblyomma species, it is reasonable to infer that all African Amblyomma species could be competent vectors of this pathogen. However, this assumption should be confirmed. In this context, it is worth mentioning the recent finding of the intergration of $R$. africae chromosome in the nuclear genome of $A$. variegatum, which can have major implications on detection specificity of $R$. africae in Amblyomma species [27].

Different studies conducted between 2003 and 2016 in the African continent (Table 2) report other tick species in which $R$. africae DNA was found such tick species belong to Haemaphysalis, Hyalomma and Rhiphicephalus genera. However, the available data does not provide direct evidence of vector competence for any of these vectors. All the studies that had such 
reports indicated that the ticks were collected from vertebrate hosts hence the $R$. africae DNA detected could have been from the blood meals they had on the hosts and not due to infection of the tick tissues with the Rickettsia. Therefore, there is a need for further investigation on $R$. africae vector competence. In addition to the above mentioned ticks, $R$. africae was also detected in fleas collected from migratory birds [28].

\section{Mammalian hosts as reservoirs of $R$. africae}

On the African continent, A. hebraeum and $A$. variegatum, the main vectors for $R$. africae, have a wide host range that includes domestic and wild species [29]. These vectors show a marked preference for large animal species and thus prefer cattle to other domestic species such as goats, sheep and donkeys. Among wild species, buffalo, eland, giraffe and kudus are preferred [13]. These wild ungulates are of major importance to the ecology of the Rickettsia species in areas where domestic animals are dipped intensively or where these animals are absent [13]. The adult stages of these ticks feed on wild ungulates. The hosts for larvae and nymphs are the same as those for adult ticks, however, they can also feed on lizards, small mammals and ground-feeding birds [30]. Humans are accidental hosts for these ticks and legs are the usual attachment sites for them. The ticks can also crawl on the skin and may be found attaching to the groin or axilla, where there is moisture [13]. These ticks respond to stimuli like carbon dioxide, ammonia, humidity, aromatic chemicals, airborne vibration and body temperature, all of which are strongly associated with their predilection sites on their hosts [31].

Ticks require blood meals for their continued development, reproduction and survival. Cattle play an important role in the ecology of $R$. africae by maintaining tick populations [18]. Serological surveys in cattle, conducted in Zimbabwe, using the immunofluorescence antibody (IFA) assay, showed that $80-100 \%$ of animals have antibodies against SFG rickettsiae $[32,33]$. In spite of the serological evidence indicating exposure to $R$. africae, no clinical signs associated to infection with $R$. africae have been reported in animals.

Experimental studies on the pathogenesis of SFG rickettsiae in Zimbabwe suggest the maintenance of the pathogen in cattle [32]. All sero-negative cattle $(n=8)$, experimentally infected with rickettsia organisms isolated from $A$. hebraeum ticks and cultured in Vero cells, were found to be positive on IFAT after three days post-infection. To determine ricketsiemia in these cattle, sero-negative guinea pigs were inoculated with blood from the experimentally infected cattle. All guinea pigs sero-converted, indicating that these cattle were rickettsemic for at least 32 days post-infection [32]. This constituted the first experimental evidence of the possible role of cattle as reservoirs for $R$. africae. However, it is worth pointing out that this suggestion is solely based on the sero-conversion in cattle and guinea pigs, which should be regarded with caution considering the low specificity of Rickettsiae serological assays. To confirm bovine hosts as reservoirs of $R$. africae, experiments using DNA-based methods should be performed. The uncertainty of the role of cattle as $R$. africae reservoirs is further corroborated by a study conducted in Kenya, where no rickettsemia was detected in cattle, sheep and goats, while $92.6 \%$ of $A$. variegatum recovered from the same animals tested positive $R$. africae DNA [18]. The scarcity of studies on $R$. africae diversity and the role of cattle or any other mammalian hosts as $R$. africae reservoirs has been recognised as a major gap in the understanding of $R$. africae epidemiology in the African continent.

Transovarial transmission of $R$. africae is well documented [22]. However, there are no studies on the efficiency of transovarial transmission for several generations in Amblyomma ticks. This is of great importance since it can provide conclusive evidence on whether $R$. africae can be maintained in its vector without the need for mammalian hosts as reservoirs.

\section{$A T B F$ presentation in different populations}

Cases of ATBF in humans usually occur in clusters. This is because of the feeding habits of Amblyomma ticks; they hide in their microhabitats and attack hosts as they appear. This is especially noticed in tourists visiting endemic areas [34]. ATBF presents with flulike symptoms with fever, nausea, fatigue, headache and myalgia. Most of the cases in Table 1 were associated with these common ATBF clinical signs. The disease is usually self-limiting. However, in the elderly and immunocompromised individuals, it can be more severe. Some ATBF cases in Table 1 were associated with complications such as chronic fatigue, reactive arthritis, encephalitis, myocarditis and cellulitis have also been reported, but mostly in the elderly [35]. Complicated ATBF in a 40-year-old Italian traveller returning from Zimbabwe was reported to have painful sacral syndrome characterised by severe pain on the leg, urinary retention and faecal incontinence and rectal tenesmus and these were attributed to be due to immune mediated mechanisms [36]. Duval and Merrill (2016), also reported a 
complicated case of ATBF where retinitis was the main symptom in a 67 year old lady from Canada [37].

Tick bite sites appear as either single or multiple inoculation eschars [35]. The typical inoculation eschar associated with ATBF consists of a central black crust surrounded by a red halo, occurring as a result of inflammation [9]. Acute cases have been reported in travellers from Europe and America after they visited southern African countries [38]. A report by Frean et al. (1998), indicated an estimated infection rate of $4-5 \%$ in foreign travellers visiting South Africa [9]. Clinical signs usually appear after they return to their country of origin since the incubation period of ATBF is five to ten days [24]. ATBF is a self-limiting disease hence many people may be affected and they do not visit hospitals for treatment. The disease can also be misdiagnosed for other diseases which present with fever like malaria and typhoid. This could be the case in many African countries where proper diagnostic laboratories and facilities are lacking. Difficulty in diagnosing the disease in the indigenous population could be also attributed to pigmented skin since it could be very difficult to notice the inoculation eschars hence such pathognomonic features of the disease are easily missed [21].

Although underreporting and misdiagnosis of ATBF can contribute to the underestimation of the disease in populations from endemic regions, the epidemiology of this infection in African rural areas strongly suggests early exposure leading to the establishment of endemic stability in these populations [22]. Furthermore, there are limited publications on the seroprevalence of $R$. africae in the rural population in areas where the tick vector exists [13], which makes it difficult to determine the status of immunity to this pathogen at population level.

\section{Conclusions}

Rickettsiae africae, transmitted by A. variegatum and $A$. hebreaum, was definitively associated with ATBF in 1996. Since then, the organism's DNA has been detected in other Amblyomma species, both in the African and American continents. Furthermore, $R$. africae DNA has also been detected in tick species other than Amblyomma. Further studies on the vector competence of other tick genera for this pathogen should be performed in order to fully clarify the dynamics of $R$. africae infection in different ecological niches. Literature on the role of mammalian hosts is scarce and contradictory. Moreover, in spite of the confirmation of transovarial transmission, the capacity for vertical transmission for several generations has yet to be fully elucidated.

A striking feature of the clinical presentation of ATBF is the marked difference between humans from presumed naïve populations and those from endemic regions since almost all of the reported ATBF cases reported worldwide were from international travellers after trips to ATBF endemic areas. In order to confirm whether endemicity is the cause of the sporadic occurrence of clinical signs from humans in rural areas of Africa, structured serological surveys including different age cohorts should be conducted.

This review highlights significant gaps in $R$. africae research, which, if addressed, will result in the better comprehension of ATBF epidemiology.

\section{Acknowledgements}

The authors would like to thank Ms Inês Neves, a medical writer, who assisted in the final preparation of the manuscript.

\section{References}

1. Kelly PJ, Beati L, Mason PR, Matthewman LA, Roux V, Raoult D (1996) Rickettsia africae sp. nov., the etiological agent of African tick bite fever. Int J Syst Bacteriol 46: 611614.

2. Jensenius M, Fournier PE, Kelly P, Myrvang B, Raoult D (2003) African tick bite fever. Lancet Infect Dis 3: 557-564.

3. Nuttall GHF (1911) On symptoms following tick-bites in man. Parasitology 4: 89-93.

4. Troup JM, Pijper A (1931) Tick-bite fever in Southern Africa. Lancet 2: 1183-1186.

5. Conor A, Bruch A (1910) An eruptive fever observed in Tunisia. Bull Soc Path Exot 3: 492-496. [Article in French].

6. Pijper A (1934) Tick-bite fever: a clinical lecture. S Afr Med J 8: 551-556.

7. Pijper A, Crocker CG (1938) Rickettsioses of South Africa. S Afr Med J 12: 613-630.

8. Fournier PE, Roux V, Caumes E, Donzel M, Raoult D (1998) Outbreak of Rickettsia africae infections in participants of an adventure race in South Africa. Clin Infect Dis 27: 316-323.

9. Frean, Blumberg, Ogunbanjo (2008) Tick bite fever in South Africa. SAFP 50: 33-35.

10. Frean J, Grayson W (2019) South African tick bite fever: an overview. Dermatopathology 6: 70-76.

11. Kelly P, Matthewman L, Beati L, Raoult D, Mason P, Dreary M, Makombe R (1992) African tick-bite fever : A new spotted fever group rickettsiosis under an old name. Lancet 340: 982983.

12. Burgdorfer W, Ormsbee RA, Schmidt ML, Hoogstraal H (1973) A search for the epidemic typhus agent in Ethiopian ticks. Bull World Health Organ 48: 563-569.

13. Jensenius M, Fournier PE, Vene S, Hoel T, Hasle G, Henriksen AZ, Hellum KB, Raoult D, Myrvang B, Norwegian African tick bite fever study group (2003) African tick bite fever in travelers to rural Sub-Equatorial Africa. Clin Infect Dis 36: 1411-1417. 
14. Roux V, Fournier P (1996) Differentiation of spotted fever group rickettsiae by sequencing and analysis of restriction fragment length polymorphism of PCR-amplified DNA of the gene encoding the protein rOmpA. J Clin Microbiol 34: 20582065.

15. Stenos J, Graves SR, Unsworth NB (2005) A highly sensitive and specific real-time PCR assay for the detection of spotted fever and typhus group rickettsiae. Am J Trop Med Hyg 73: $1083-1085$.

16. Kumsa B, Socolovschi C, Raoult D, Parola P (2019) Spotted fever group rickettsiae in ixodid ticks in Oromia, Ethiopia. Ticks Tick Borne Dis 6: 8-15.

17. Walker AR, Bouattour A (2003) Ticks of domestic animals in Africa : A guide to identification of species. Edinburgh: Biosci Rep. 3-210.

18. Maina AN, Jiang J, Omulo SA, Cutler SJ, Ade F, Ogola E, Feikin DR, Njenga MK,Cleaveland S, Mpoke S, Ng'ang'a Z (2014) High prevalence of Rickettsia africae variants in Amblyomma variegatum ticks from domestic mammals in rural western Kenya : implications for human health. Vector Borne Zoonotic Dis 14: 693-702.

19. Tomassone L, Meneghi D De, Adakal H, Rodighiero P, Pressi G, Grego E (2016) Detection of Rickettsia aeschlimannii and Rickettsia africae in ixodid ticks from Burkina Faso and Somali region of Ethiopia by new real-time PCR assays. Ticks Tick Borne Dis 7: 1082-1088.

20. Kelly PJ, Mason PR (1991) Transmission of a spotted fever group rickettsia by Amblyomma hebraeum (Acari: Ixodidae). J Med Entomol 28: 598-600.

21. Kelly PJ (2006) Rickettsia africae in the West Indies. Emerg Infect Dis 12: 224-226.

22. Kelly PJ, Mason PR (1991) Tick-bite fever in Zimbabwe. Survey of antibodies to Rickettsia conorii in man and dogs, and of Rickettsia-like organisms in dog ticks. South African Med J 80: 233-236.

23. Socolovschi C, Huynh TP, Davoust B, Gomez J, Raoult D, Parola P (2009) Transovarial and trans-stadial transmission of Rickettsiae africae in Amblyomma variegatum ticks. Clin Microbiol Infect 15: 317-318.

24. Eldin C, Mediannikov O, Davoust B, Cabre O, Barré N, Raoult D, Parola P (2011) Emergence of Rickettsia africae, Oceania. Emerg. Infect. Dis 17: 100-102.

25. Dietrich M, Lebarbenchon, Camille Jaeger A, Le Rouzic C, Matthieu B, Lagadec E, McCoy KD, Pascalis H, Le Corre M, Dellagi K, Tortosa P (2014) Rickettsia spp. in seabird ticks from western Indian Ocean islands, 2011-2012. Emerg Infect Dis 20: 838-846.

26. Vogel H, Foley J, Fiorello CV. (2018) Rickettsia africae and novel rickettsial strain in Amblyomma spp ticks, Nicaragua, 2013. Emerg Infect Dis 24: 385-387.

27. Darby AC, Al-Khafaji AM, Whitehead M, Hartley CS, Robinson G, Armstrong SD, Beliavskaia AY, Bah GS, Githaka N, Bell-Sakyi L, Makepeace B (2019) Amblyomma variegatum, vector of African tick-bite fever, contains an integrated Rickettsia africae chromosome in its nuclear genome. Am J Trop Med Hyg 101: 211.

28. Sekeyová Z, Mediannikov O, Roux V, Subramanian G, Špitalská E, Kristofík J, Darolová A, Raoult D (2012) Identification of Rickettsia africae and Wolbachia sp. in Ceratophyllus garei fleas from passerine birds migrated from Africa. Vector Borne Zoonotic Dis 12:539-543.

29. Halajian A, Palomar AM, Portillo A, Heyne H, Romero L, Oteo JA (2018) Detection of zoonotic agents and a new
Rickettsia strain in ticks from donkeys from South Africa: implications for travel medicine. Travel Med Infect Dis 26: 4350 .

30. Socolovschi C, Huynh TP, Davoust B, Gomez J, Raoult D, Parola P (2009) Transovarial and trans-stadial transmission of Rickettsiae africae in Amblyomma variegatum ticks. Clin Microbiol Infect 15: 317-318.

31. Althaus F, Greub G, Raoult D, Genton B (2010) African tickbite fever: a new entity in the differential diagnosis of multiple eschars in travelers. Description of five cases imported from South Africa to Switzerland. Int J Infect Dis 14: 274-276.

32. Kelly PJ, Mason PR, Manning T, Slater S (1991) Role of cattle in the epidemiology of tick-bite fever in Zimbabwe. J Clin Microbiol 29: 256-259.

33. Parola P, Davoust B, Raoult D (2005) Tick- and flea-borne rickettsial emerging zoonoses. Vet Res 36: 469-492.

34. Caruso G, Zasio C, Guzzo F, Granata C, Mondardini V, Guerra E, Macri E, Benedetti P (2002) Outbreak of African tick-bite fever in six Italian tourists returning from South Africa. Eur J Clin Microbiol Infect Dis 21: 133-136.

35. Nilsson K, Wallménius K, Rundlöf-nygren P, Strömdahl S (2017) African tick bite fever in returning Swedish travellers. Report of two cases and aspects of diagnostics. Infect Ecol Epidemiol 07: 1343081.

36. Zammarchi L, Farese A, Trotta M, Amantini A, Raoult D, Bartoloni A (2014) Rickettsia africae infection complicated with painful sacral syndrome in an Italian traveller returning from Zimbabwe. Int J Infect Dis 29: 194-196.

37. Duval RM, Merrill PTM (2016) Spotted fever group rickettsia retinitis in a traveler to Africa. Retin Cases Br Reports 10: 8992.

38. Parola P (2006) Rickettsioses in sub-Saharan Africa. Ann N Y Acad Sci 1078: 42-47.

39. Uslan DZ, Sia IG (2004) African tick bite fever: Mayo Clin Proc 79: 1007.

40. Jackson Y, Chappuis F, Loutan L (2004) African tick-bite fever: four cases among Swiss travelers returning from South Africa. J Travel Med 11: 225-228.

41. Bellini C, Monti M, Potin M, Dalle Ave A, Bille J, Greub G (2005) Cardiac involvement in a patient with clinical and serological evidence of African tick-bite fever. BMC Infect Dis 5: $1-6$.

42. Snape MD, Pollard AJ (2006) African tick bite fever. Lancet Infect Dis 6: 750.

43. Owen CE, Bahrami S, Malone JC, Callen JP, Kulp-shorten CL (2006) African tick bite fever. Arch. Dermatol 142: 13121314.

44. Roch N, Epaulard O, Pelloux I, Pavese P, Brion J, Raoult D, Maurin M (2008) African tick bite fever in elderly patients: 8 cases in French tourists returning from South Africa. Clin Infect Dis 47: e28-e35.

45. Schuster J, Tantcheva-Poor I, Wickenhauser C, Chemnitz JM, Hunzelmann N, Krieg T, Hartmann K (2008) African tick bite fever - Papulovesicular exanthem with fever after staying in South Africa. JDDG 6:379-381.

46. Consigny PH, Ina S, Fraitag S, Rolain JM, Buffet P (2009) Unusual location of an inoculation lesion in a traveler with African tick-bite fever returning from South Africa. J Travel Med 16: 439-440.

47. Tsai KH, Lu HY, Huang JH, Fournier PE, Mediannikov O, Raoult D, Shu PY (2009) African tick bite fever in a Taiwanese traveler returning from South Africa: molecular and serologic studies. Am J Trop Med Hyg 81: 735-739. 
48. Tappe D, Dobler G, Stich A (2009) Images in clinical tropical medicine: Tache noire in African tick bite fever. Am J Trop Med Hyg 81: 733-734.

49. Tomasiewicz K, Krzowska-Firych J, Bielec D, Socolovschi C, Raoult D (2015) First case of imported African tick-bite fever in Poland - case report. Ann Agric Environ Med 22: 412-413.

50. Schwartz RA, McElligott S, Lambert C, Kapila R (2012) Mucocutaneous leishmaniasis and African rickettsial tick-bite fever: A combination of exotic traveler's disease in the same patient. J Am Acad Dermatol 66: AB110.

51. Chmielewski T, Szymanek A, Maçzka I, Fiecek B, Simon K, Tylewska-Wierzbanowska S (2013) Case report of African tick-bite fever from Poland. Postep Dermatologii i Alergol 30: 396-398.

52. Antal AS, Flaig MJ, Schneck C, Thoma B, Herzinger T (2013) Souvenir from South Africa. Infection 41: 597-598.

53. Yankura J, Ioffreda MD (2014) Necrotic plaques in a traveler. J Am Acad Dermatol 70: 959-961.

54. Cox JA, Visser LG (2015) A family with African tick bite fever. Travel Med Infect Dis 13: 274-275.

55. Bohaty BR, Hebert AA (2015) Images in clinical medicine: African tick-bite fever after a game-hunting expedition. N Engl J Med 372: e14.

56. Franon E, Manckoundia P (2015) Memory of an exotic holiday. Eur J Intern Med 26: e57-e58.

57. Binder WD, Gupta R (2015) African tick-bite fever in a returning traveler. J Emerg Med 48: 562-565.

58. Hauser N, Arzomand Z, Fournier J, Breen C, Jamali L, Cossman J, Tandon R (2016) A case of African tick-bite fever in a returning traveler. IDCases 5: 78-79.

59. Harrison N, Burgmann H, Forstner C, Ramharter M, Széll M, Schötta AM, Stanek G, Markowicz M (2016) Molecular diagnosis of African tick bite fever using eschar swabs in a traveller returning from Tanzania. Wien Klin Wochenschr 128: 602-605.

60. Bogovic P, Lotric-Furlan S, Korva M, Avsic-Zupanc T (2016) African tick-bite fever in traveler returning to Slovenia from Uganda. Emerg Infect Dis 22: 1848-1849.

61. Albízuri Prado F, Sánchez A, Feito M, Mayor A, Rodriguez A, de Lucas R (2017) Fever and multiple eschars after an African Safari: Report of three cases. Pediatr Dermatol 34: e179-e181.

62. Armitano R, Guillemi E, Borras P, Govedic F, Lopez JL, Farber M, Prieto M (2018) African tick bite fever: First imported cases diagnosed in Argentina. Int J Infect Dis 73: 199.

63. Liao E, Carr D (2017) A tale of black eschar in a returning traveller. J Emerg Med 53: 904-906.

64. Menzer C, Fink C, Enk A, Haenssle HA (2017) African tickbite fever - a tantalizing souvenir from South Africa. JDDG J Ger Soc Dermatology 15: 1027-1028.

65. Strand A, Paddock CD, Rinehart AR, Condit ME, Marus JR, Gillani S, Chung IH, Fowler Jr VG (2017) African tick bite fever treated successfully with rifampin in a patient with doxycycline intolerance. Clin Infect Dis 65: 1582-1584.

66. van Geffen MW, van Niekerk JM, Posthouwer D (2018) A patient with fever and skin lesions after vacation in South Africa. A skin lesion after a visit to South Africa; what is your diagnosis? Neth J Med 62: 134.

67. Angerami RN, Krawczak FS, Nieri-Bastos FA, Santos F, Medorima C, Resende MR, Labruna MB (2018) First report of African tick-bite fever in a South American traveler. SAGE Open Med Case Reports 6: 2050313X18775301.
68. Johnson KR, Schupack DA, Virk A (2019) 31-year-old South African man with fever and headache. Mayo Clin Proc 94: 336-340.

69. Kolo A, Sibeko-Matjila KP, Maina A, Richards AL, Knobel DL, Matjila PT (2016) Molecular detection of zoonotic Rickettsiae and Anaplasma spp. in domestic dogs and their ectoparasites in Bushbuckridge, South Africa. Vector Borne Zoonotic Dis 16: 245-252.

70. Mediannikov O, Diatta G, Zolia Y, Cellou M, Kohar H (2012) Tick-borne rickettsiae in Guinea and Liberia. Ticks Tick Borne Dis 3: 43-48.

71. Kernif T, Djerbouh A, Mediannikov O, Ayach B, Rolain JM, Raoult D, Parola P, Bitman I (2012) Rickettsia africae in Hyalomma dromedarii ticks from sub-Saharan Algeria. Ticks Tick Borne Dis 3: 377-379.

72. Abdel-shafy S, Mediannikov O, Parola P, Raoult D (2012) Molecular detection of spotted fever group rickettsiae associated with ixodid ticks in Egypt. Vector Borne Zoonotic Dis 12: $346-359$.

73. Sambou M, Faye $\mathrm{N}$, Bassène $\mathrm{H}$, Diatta G, Raoult $\mathrm{D}$, Mediannikov O (2014) Identification of rickettsial pathogens in ixodid ticks in northern Senegal. Ticks Tick Borne Dis 5: $552-556$.

74. Mutai BK, Wainaina JM, Magiri CG, Nganga JK, Ithondeka PM, Njagi ON, Jiang J, Richards AL, Waitumbi JN (2013) Zoonotic surveillance for Rickettsiae in domestic animals in Kenya. Vector-Borne Zoonotic Dis 13: 360-366.

75. Hornok S, Abichu G, Meli ML, Tánczos B, Sulyok KM, Gyuranecz M, Gönczi E, Farkas R, Hofmann-Lehmann R (2014) Influence of the biotope on the tick infestation of cattle and on the tick-borne pathogen repertoire of cattle ticks in Ethiopia. PLoS One 9: e106452.

76. Kumsa B, Socolovschi C, Raoult D, Parola P (2015) Spotted fever group rickettsiae in ixodid ticks in Oromia, Ethiopia. Ticks Tick Borne Dis 6: 8-15.

77. Ogo NI, de Mera IGF, Galindo RC, Okubanjo O, Inuwa HM, Agbede RI, Torina A, Alongi A, Vicente J, Gortázar C, de la Fuente J (2012) Molecular identification of tick-borne pathogens in Nigerian ticks. Vet Parasitol 187: 572-577.

78. Yssouf A, Socolovschi C, Kernif T, Temmam S, Lagadec E, Tortosa P, Parola P (2014) First molecular detection of Rickettsia africae in ticks from the Union of the Comoros. Parasit Vectors 7: 1-6.

79. Mediannikov O, Diatta G, Fenollar F, Sokhna C, Trape JF, Raoult D (2010) Tick-borne rickettsioses, neglected emerging diseases in rural Senegal. PLoS Negl Trop Dis 4: e821.

80. Macaluso KR, Davis J, Alam U, Korman AM, Rutherford JS, Rosenberg R, Azad AF (2003) Spotted fever group rickettsiae in ticks from the Masai Mara region of Kenya. Am J Trop Med Hyg 68: 551-553.

\section{Corresponding author}

Dr Estere Mazhetese BVSc. MSc.

University of Pretoria, Faculty of Veterinary Science

M35 Onderstepoort

Pretoria 0110

Tel: +27640874929

Fax: + 27125298312

Email: emazhets@gmail.com

Conflict of interests: No conflict of interests is declared. 